Editorial

\title{
Feminism from the Perspective of Catholic Theology
}

\author{
Tracey Rowland
}

School of Philosophy and Theology, University of Notre Dame (Australia), Sydney 2007, Australia; tracey.rowland@nd.edu.au

Received: 7 September 2020; Accepted: 23 September 2020; Published: 4 November 2020

The first time I visited this topic was back in 2015, when I was invited to a debate at El Escorial with one of the leading Spanish feminists. The debate was organized by Fr Javier Prades, the Dean of the University of San Damáso, in Madrid. It was a very enjoyable experience and a genial exchange of positions. This special edition of Religions addressing the same topic is also undertaken in a genial spirit. It brings together a collection of six essays by scholars who are practicing Catholic women who share a professional interest in philosophical and theological anthropology.

To bring the intellectual and social movement known as feminism into juxtaposition with Catholic theology is not a simple exercise since the movement is not a united front. Unlike the Catholic Church, which does have an internal organ dedicated to doctrinal oversight-the Congregation for the Doctrine of the Faith-as well as various documents of popes and Church Councils described as being of "magisterial" standing that clarify teachings on different topics, feminism is a much more centrifugal force. There are many different "species" of feminist scholars such as first wave, second wave, third wave and fourth wave, essentialist and constructivist and radical, to name just some of the most prominent of the sub-divisions. This means that when one seeks to examine the movement from the perspective of Catholic theology one has to be careful of making generalisations. Something that might be held as a doctrinal position by one group of feminists may be hotly disputed by another group. There are also numerous different foci to be chosen. Depending on the given issue, there may or may not be some high level of congruence between Catholic and feminist thought. For example, some feminists will regard women's access to in vitro fertilization as a "right", while others will be highly critical of the whole process of in vitro fertilization and interpret it as a violation of a women's body by masculine technology. Some feminists, often described as 'essentialists' believe that if a person is born a female, then she remains a woman for life. Others, described as constructivists, reject such essentialism and argue that both masculinity and femininity are mere social constructs, and, as a logical consequence, they are supportive of gender fluidity movements. It is therefore possible to have numerous different analyses of the Catholic-feminist relationship.

The Catholic scholars invited to contribute to this collection have tended to focus on two major areas. The first is Simone de Beauvoir's thesis that women have been socially conditioned to regard themselves as the "Second Sex". It has often been argued that the Catholic Church, and, indeed, Christianity in general, has been complicit in this conditioning. The first paper in the collection, by Deborah Savage, concedes this argument to the feminists. She offers a genealogy of the "Second Sex" mentality that begins with the pre-Socratic philosophers and is then given traction by Aristotle's judgment that women are merely "malformed males" and by a "flawed historical interpretation of Genesis 2:18-23", traceable to the philosopher Philo (BC13-AD 54). The first half of her paper tracks the development of the "Second Sex" interpretation from certain interpretations of the book of Genesis and of human biology, while the second half offers her own revisiting of Genesis 1 and 2, along with an engagement with the magisterial teachings of St. John Paul II. Between the two positions, she identifies the theology of St. Thomas Aquinas as a watershed moment in the Catholic understanding of the significance of sexual difference and the ontological standing of women. She situates Aquinas at the 
beginning of a long historical process that "unpicks" the errors in the intellectual tapestry sown by Aristotle and Philo, among others. She writes:

Aquinas is operating within a horizon of grace, permitting him to maintain and leverage a fundamental premise of Catholic theology, that "grace perfects nature". This gives him free reign to argue that, though woman starts life as a "lesser" creature, in the end, she may arrive at a full relations of sex complementarity with man. She has the capacity to develop, and, under the influence of grace, she can achieve a full equality with man and be equally capable of infused wisdom and the theological virtues of faith, hope and love. In his account, man is not superior to woman in the realm of the divine; in heaven, man and woman are equal.

Savage concludes that, though it must be admitted that Catholic scholars have over the centuries made mistakes, the Church's 'affirmation of the differences between man and woman can be acknowledged without compromise to woman's essential ontological equality'. She believes that it is therefore possible to articulate a feminist approach to sex difference that is completely in accord with magisterial teaching by relying on categories that are themselves part of the fabric of the Catholic tradition but not a part of the tapestry that owes its development to "Second Sex" style interpretations of the book of Genesis.

The second essay in the collection by Margaret Harper McCarthy also begins with a reference to de Beauvoir's The Second Sex. Instead of offering an interpretation of sexual difference in the book of Genesis, McCarthy is focused on the Pauline notion of headship to be found in the New Testament. Like Savage, she acknowledges that, in many instances, the Christian tradition failed to acknowledge the full equality of man and woman but she nonetheless argues that none of this negates the fact that Christian Revelation from the beginning sowed the seeds for the development of an understanding of ontological equality within difference. In this context, she places special emphasis on the Trinitarian nature of the Godhead as it is understood in Catholic theology. Each of the Persons within the Trinity is of equal dignity to the others, even though they are different Persons. The Trinity is thus a model of a relationship of equality within difference. Thus, McCarthy's inquiry takes up the charge, typical of second wave feminism, 'that order and equality are incompatible bedfellows'. McCarthy argues that not only are they compatible, but that 'they are necessary to each other if the "fellows" are not to be merely standing next to each other on a "spectrum", but rather turned toward each other, already belonging to each other, and generously so, in an insurmountable (and fruitful) unity in distinction'.

Catholic theological engagements with feminism often entail a discussion of the relationship between Eve, the first woman of the Genesis narrative, and Mary, who is often described as the Second Eve. Just as Savage offered an interpretation of the Genesis account of creation, which affirms the original equality of man and woman, Mary Frances McKenna develops the Mariology of Joseph Ratzinger in conjunction with his notion of person and his scriptural exegesis, where he identifies a "female line" in the Bible. Specifically she considers Ratzinger's work where he 'typologically links the taking of Eve from Adam's side to the piercing of Christ's side and the creation of the new community of the Church'. McKenna extrapolates from Ratzinger's work that the "male line" is the Bible represents "humanity", every human being both male and female, while the "female line" represents the communal aspect of humanity.

These three papers, in different ways, could be described as responses to the charge that Christianity in general, and Catholic theology in particular, has been responsible for fostering the "Second Sex" mentality. They each suggest that a guilty plea may well be entered but they also seek to mitigate and defend from within the resources of the Catholic intellectual tradition itself. They are all of the view that not only is it possible to defend the ontological equality of man and woman by recourse to the sacred books of the Old and New Testaments, but they go further and argue that it is precisely these resources that provide a firmer foundation for the defense of the equal dignity of man and woman than many secular feminist foundations. What many feminist accounts lack is something like a Trinitarian 
relational metaphysics which explains how difference and equality, order and equality, can work in tandem.

The fourth of the papers in the collection also takes the work of Simone de Beauvoir as a starting point, but instead of focusing upon the "Second Sex" problem, Renée Köhler-Ryan engages with the argument that, by taking biology seriously, one inevitably ends with an unsophisticated essentialism with major political consequences. Whereas the first three authors had recourse to scriptural exegesis to deal with the "Second Sex" issue, Köhler-Ryan deals with essentialism by an engagement with the philosophical and theological anthropology of Edith Stein, otherwise known by her religious name, St. Teresa-Benedicta of the Cross. She argues that Stein is what Nancy A Dallavalle calls a "critical essentialist". Stein was the precursor to what St. John Paul II was to call "new feminism"—a feminism consistent with Trinitarian anthropology, exemplified in the works of contemporary Catholic scholars such as Michele Schumacher and Helen Alvaré. Köhler-Ryan notes that accepting that biology is theologically relevant often puts the New Feminists at odds with postmodern philosophers such as Judith Butler. However, the flip side of this is that Catholic New Feminists have much more to say about the relevance of embodiment. As Elizabeth Fox-Genovese explains 'Catholicism views body and soul as indissolubly linked' and this opens the door to an understanding of equality and difference.

One of the most significant aspects of feminine "embodiment" is the ability to nurture life within the womb. This theme is taken up by Anna Krohn in the fifth paper, which explores the parallel theme of maternity in the works of the Bulgarian philosopher Julia Kristeva and St. John Paul II. Krohn argues that the Encyclical Evangelium Vitae (the Gospel of Life) contains the seeds of "a new vision of maternity" which is integral to the development of a "new feminism" and to a "a culture of life."

Finally, Helenka Mannering explores the rapprochement between the Feminist Ethics of Care and contemporary Catholic moral theology. The Feminist Ethics of Care stands opposed to utilitarianism and the abstract, disembodied character of Kantian moral theology. In taking this position, proponents of the Feminist Ethics of Care often find themselves occupying the same ground as Catholic moral theologians. In particular, Catholic moral theologians and feminist proponents of Care Ethics each argue for a relational anthropology that differs from the typical individualistic view of the human person that flows from the liberal tradition. A hallmark of such liberal views is a focus on human autonomy rather than human solidarity. Mannering finds the convergence of positions of these two groups to be a positive development. She concludes that the anthropological and moral theology of the two scholar popes, St. John Paul II and Benedict XVI, would offer the Ethics of Care a deeper ontological and epistemological grounding, hence strengthening its viability and existential appeal.

This notion of an ontological and epistemological grounding is the intellectual gift, so to speak, which Catholic theology offers to the feminist movement. However, an openness to receive the gift requires feminists to overcome the fear that they might be accepting something that is a Trojan horse for a further round of "second-sex thinking". This makes the papers by Savage, McCarthy and McKenna particularly important. Köhler-Ryan's paper further offers feminists who are tempted to explore the Catholic intellectual treasury a window into the philosophical and theological anthropology of Edith Stein, who is, by far, the most important Catholic author to address the subject of sexual difference in the modern era. Finally, Anna Krohn's contribution can be showcased as an example of what may be achieved if Catholic scholars track the social concerns of feminist scholars and analyse them within the framework of St. John Paul II's theology of the body. As Mannering emphasizes, feminist proponents of an Ethics of Care are right to go to war against the disembodied character of moral theories with a Kantian pedigree. 
Funding: This research received no external funding.

Conflicts of Interest: The author declares no conflict of interest.

Publisher's Note: MDPI stays neutral with regard to jurisdictional claims in published maps and institutional affiliations.

(C) 2020 by the author. Licensee MDPI, Basel, Switzerland. This article is an open access article distributed under the terms and conditions of the Creative Commons Attribution (CC BY) license (http://creativecommons.org/licenses/by/4.0/). 